\title{
Inequality in the Dynamics of Development: Post-Globalisation Changes and 21st Century Challenges
}

Mofidul Hassan ${ }^{+*}$ and M P Bezbaruah

\section{Abstract}

Following Kuznets' pioneering works, the growth-inequality nexus was stylised as an inverted Ushaped relation. As per that paradigm, economic inequality initially increases when a nation embarks upon a modern economic development process, but later on, declines as the development process cross a certain threshold. The paradigm roughly bears out the experience of the industrialised countries of Europe and North America from the beginning of the nineteenth century up to the mid-1970s. The inevitability of the pattern came under question when data from a broader range of countries became available by the 1970s. Then the post-globalisation experience of countries around the world virtually negated the falling part of Kuznets inverted U. Most countries which profited from globalisation in the form of upward shifts of their growth trajectories also experienced a rise rather than a decline in economic inequality. The present paper is a survey of the large and interesting literature on the changing nature of inequality before and after globalisation. The survey finds that inequality across countries has actually declined as a result of globalisation whereas inequalities within countries have almost invariably increased. Apart from usual factors such as bequest and skewed distributions of wealth, the new factors that have accentuated postglobalisation inequality are widening wage disparities, inequalities of opportunities, the onslaught of automation and rent-seeking activities of a section of the rich. The survey also notes how inequality has been moderated in some counties through effective taxes and transfer programmes. After summarising the arguments why growing economic inequality cannot be left unattended, the survey concludes with an outline of the policy choices which are being currently discussed in the academic and administrative circles.

Keywords: Economic Inequality; Trade-off; Fair and Unfair Inequality; Elephant Curve; Globalisation

\footnotetext{
${ }^{\dagger}$ Assistant Professor, Department of Economics, Pandit Deendayal Upadhyaya Adarsha Mahavidyalaya Tulungia, Bongaigaon, Assam

${ }^{*}$ Corresponding Author, Email: mofidulhassan@gmail.com

¥Professor, Department of Economics, Gauhati University, Guwahati, Assam

Email: bezbaruah.mp@gmail.com

(C) 2020 Hassan \& Bezbaruah. This is an Open Access article distributed under the terms of the Creative Commons Attribution License (http://creativecommons.org/licenses/by/2.0), which permits unrestricted use, distribution, and reproduction in any medium, provided the original work is properly cited.
} 


\section{Introduction}

A subject which has received the attention of thinkers and researchers in the 21st Century is the growing economic inequality in most parts of the globe. According to early thinking in Development Economics, inequality first increases when, an economy embarks upon the modern development process, but later declines as development level crosses a certain threshold. This pattern seemed to bear out the experience in western industrialised countries in the 19th Century and the better part of the 20th Century. However, since the mid-1970s, as globalisation gathered momentum and countries in different parts of the world shifted to higher growth trajectories, inequalities began to rise rather than decline further. The rise in inequality in the last four decades has caught the attention of many scholars who have looked into its nature and dimensions, geographical pattern, causal factors of inequality and the possible ways of mitigating it. The present study is an attempt to capture the gist of this vast and growing literature with the expectation that interested readers, researchers and administrators will find the write-up useful as a ready reference to the subject.

The study has been organised in six sections. The next section is a review of the theoretical debate on the growth-inequality nexus. The section following this describes the post-globalisation paradigm of inequality. It then goes to discuss the factors contributing to accentuation of inequality within countries. This is followed by a section recounting the arguments why inequality cannot be left unattended. Measures suggested for addressing inequality in the 21stCentury are discussed in the concluding section.

\section{The Growth - Inequality Nexus}

In the 1950s and 1960s, economists, including Kuznets (1955) and Kaldor (1955) argued that there exists a trade-off between reducing inequality and promoting growth. The emphasis of early development economists was on raising the rate of saving in the less developed countries so that the countries could break free from the vicious circle of poverty by amassing enough capital. Striving to reduce mass poverty by reducing inequality was seen as contrary to this goal, as the poor were expected to mostly consume away their enhanced income than save the same for capital formation. Instead, a higher degree of initial inequality would yield larger aggregate saving, greater capital accumulation, and higher growth. Kuznets' empirical works extended support to the trade-off theory in the form of his inverted $U$ hypothesis. Kuznets (1963) concludes that the level of income inequality rises during the early stage of development, hits a maximum and stop rising during the middle phase, and then declines during the later stages of development. The driving force behind the whole process is industrialisation, coupled with urbanisation. To begin with, less developed economies have large proportions of their population in the traditional agricultural sector. As modern industries with higher productivity emerge, workers begin to shift from the traditional sector to higher-paying modern sectors. In the process, inequality begins to rise (Wolff, 2009). In the later stages of the development process, as benefits of growth start trickling down to the left-out sections of society, the society moves towards an equal distribution. Because of the migration of people from agriculture to industry, the pressure of population on land in rural areas decreases, leading to an increase in per capita income from land. Further, within the modern sector, expansion of education also reduces income inequality (Wolff, 2009).

Piketty (2015, pp 18-22), however, points out that the downturn in the inverted $U$, observed in the industrialised countries in the first threequarters of the 20th Century, was not so much because of the 'natural' economic process perceived by Kuznets and others but due to (a) shocks incurred by wealth owners in 1914-1945 in the forms of wars, inflation and the great depression, (b) progressive taxation first initiated by France in 1914 and then followed by others, and (c) the rise of labour unions and 
welfare measures in the post-second World War decades. Analysing Kuznets process from a political economy angle Acemoglu and Robinson (2002) argue that capitalist industrialisation tends to increase inequality, but this inequality leads to its own destruction because it induces a change in the political and policy regimes. Rising social tension from increased inequality forces equalising political reforms which eventually bend the curve downward.

With cross-country longitudinal data are becoming available since the 1970s, a counterargument to the growth-equity trade-off started to emerge. Using these data, Todaro and Smith (2013) contested Kuznets' hypothesis by showing that per capita income is not necessarily related to inequality. They pointed out that some low-income countries like Ethiopia had low inequality, whereas other low-income countries such as Mozambique and Zambia had far higher inequality. Similarly, some countries in the middle-income range had high inequality, but many middle-income countries had low inequality too. Among high-income countries also, inequality was high in the United States and Spain but low in Norway. They concluded that growth and inequality could manifest in various alternative patterns. The fundamental issue is how the size of national income is expanded; whether by a few or by many. If a few generate it, then the fruits of growth are shared by a small segment of the population; but if it is generated by the many, then the fruits of growth are shared more evenly. Alesina and Rodrik (1994), Jacobs (2000), Kurian (2000) and Persson and Tabellini (1994) also found evidence negating a standard relationship between inequality and growth.

Empirical evidence is thus ambiguous regarding the nature of nexus between inequality and growth. What these shreds of evidence establish with certainty is that a trade-off between equity and growth is not inevitable.

\section{The New Paradigm of Inequality Post Globalisation}

Globalisation process of the last part of the 20th Century, compounded with the pervasiveness of information technology, imparted a considerable change like economic activities and their organisation all over the world. There was impressive growth in the most part of the world until the process was jolted by the global financial crisis of 2007 that triggered recessions in many counties and economic slowdown in the others. The stylised patterns based on old facts and perception could no longer capture the patterns that emerged under the new dynamics. As per Kuznets' inverted $u$ hypothesis, most countries should have experienced a decline in inequality from the prolonged run of economic growth. But studies reveal that inequality actually increased in most countries including the USA, China, and India. Kuznets inverted-U curve has given way to Milanovic's Elephant Curve for portraying income distribution in the post-globalised world.

Lakner and Milanovic (2016) plotted income gain during 1998-2008 of each percentile of world population by income distribution of 1988 . The emerging curve resembles the outline of an elephant, with the trunk pointed up on the right. Corlett (2016) divides the elephant curve into three parts corresponding to three groups of income holders. The first group is around 50th percentile (global median). This population occupying the middle portion of the graph received the largest increase in income shares and thus is the prime beneficiaries of globalisation. This segment of world population is mostly comprised of the people from the emerging Asian economies, including China, India, Thailand, Vietnam, and Indonesia. The second group is around the 80th percentile. The shape of the curve implies that this group experienced a 20-year stagnation of real income. Most of the people in this group are citizens of the old-rich countries of Western Europe and North America. Milanovic (2018) calls them the lower middle class of the rich world, who are not the winners of globalisation. The third group is the wealthiest one per cent of the world's population, whose income continued to grow sharply in contrast to that of the second group. People who belong to the global top one per cent are overwhelmingly from the rich economies including the United States, Japan, and Oceania. While the elephant curve portrays some interesting feature of the change in global 
income distribution over the period concerned, the pattern is usually not distinct in the distributions within individual countries. When the elephant curve is drawn for individual countries, then it tends to slope upwards more or less continuously implying that the rich gaining more than the poor within countries (The Economist, 2016). Thus, it seems that postglobalisation inequality across nations has declined substantially, while inequalities within a nation have gone up nearly everywhere (Roy \& Roy, 2018). Milanovic (2018) referred to this phenomenon as the 'Inequality Paradox'.

Bourguignon (2015) throws further insights into the post-globalisation inequality pattern. After rising steadily for about two centuries from 1800 , he observes, inequality in standard of living among countries has started to decline since 1980. For illustration, he shows that the average standard of living in France or Germany was twenty times higher than in China or India in 1980. Two decades later, this gap was cut in half. On the other hand, inequality within most economies - developed and emerging - has increased. For an explanation Bourguignon (2015: 3-4) writes:

The expansion of international trade, the mobility of capital and labour (notably for the most skilled), and the spread of technological innovation have partially bridged the gap between the wealthiest countries and the developing countries. But, at the same time, they have also contributed to a change in income distribution within these economies. Global economic growth has led to certain lines of production emigrating from developed countries to emerging ones, with the result that the demand for unskilled labour has shrunk in more advanced countries - which has led to a drop in its relative compensation. The international mobility of top skills and the growth of global trade have meant that across the world the high end of the wage distribution falls in line with that of the countries where economic elites are the best compensated, and the income stream from capital is everywhere increasing faster than that from labour (Bourguignon 2015, pp 3-4)

Further, he points out that growth which was earlier mostly concentrated in countries constituting only about $10 \%$ of the world population has now shifted to more populous parts of the world including China and India. Thus income is getting redistributed in favour of the latter group of countries accounting for a much larger percentage of the world population. In broad conformity with Bourguignon (2015), Deaton (2013) and Milanovic (2018) also find that the gaps in average incomes of developed and developing countries have been shrinking. Nevertheless, he notes that among the developing countries, many have not been able to close the gap.

Inequalities within countries have, of course, continued to increase everywhere except in a few countries such as Denmark, the Scandinavian Countries and Vietnam in the 1990s (Vanham, 2018). In all these cases, progressive and effective taxes and transfers policies of the respective governments have had a role.

\section{Factors Contributing to Inequality Within Nations}

The scholarly works probing post-globalisation rise in inequality have identified several conventional and nonconventional factors contributing to the process of widening inequalities within countries.

Piketty (2014) sees rise in inequality as an outcome of higher-income shares accruing to capital. He shows that the long-term the historical rate of return on capital has been between $4 \%$ and $5 \%$, which is higher than the rate of growth of overall income. This, he argues, implies an ever-increasing inequality of wealth and income, in the absence of strong redistributive policies.

Nevertheless, a significant feature of postglobalisation inequality is that it has been caused not only by the unequal distribution of valueadded between labour and capital but also by wage dispersion between privileged workers in 
the formal sector (public sector and big corporations) and precarious workers with limited contracts, temporary or leased work and in the informal sector. The share of informal employment, for instance, is more than $80 \%$ in India (OECD, 2011). Widening of wage differentials is ascribed to mainly two factors, viz, inequality in educational opportunities and automation. Stiglitz (2012) observes that the high cost of education needed for high paying jobs keeps such education out of reach of the most from disadvantaged economic backgrounds. Inequality of educational opportunities not only limits the upward mobility of ordinary working-class members but by keeping competition for highly paid work limited, it allows wages for such jobs soaring. Automation process, on the other hand, has been squeezing out jobs of unskilled and semiskilled workers (Yan, 2016), thereby contributing to keeping wages for such jobs low.

Several other studies have highlighted unequal access to education and resulting disparity in human capital formation as a significant contributory factor to present-day economic inequality in different parts of the globe. Using 1980 the US Census micro-data, Bishop et al., (1992) found that inequality is directly related to the level of per capita property income and the inequality in education. Rao (1999) confirms that the same holds for eight East Asian Economies of Japan, Hong Kong, South Korea, Singapore, Taiwan, Indonesia, Malaysia, and Thailand. Using nationally representative household survey data for India for the years 1983, 1993-94 and 200405, Sarkar and Mehta (2010) find that among different variables influencing inequality years of schooling is the most significant.

Given that inequalities exist, market imperfections seem to reinforce it further. As Okun (2015, pp 77-78) puts it:

By the impersonal criterion of the ideal market, everyone contemplating the same investment project should face exactly the same interest costs. That does not happen. In fact, the projects of the well-to-do typically get favoured treatment. The reverse side of this coin of favouritism for the wealthy is discrimination against the poor. The resulting inefficiency and inequality of opportunity curb investment by the poor in setting up businesses, in buying homes, in education, and in all forms of human capital.

The problem is compounded by the fact that low-income families generally face vastly higher effective interest rates than do average households.

To the extent government interventions through taxes and transfer moderate-income distribution within counties, the gap between incomes of the rich and the poor is the result of government policy. Stiglitz (2013) reports that taxes have become less progressive as top income tax rates, corporate taxes, and wealth taxes have been reduced to prevent tax evasion, which has become more effortless in the globalised world. The tax base shifted toward consumption, sales, and value-added taxes, which are inherently regressive. However, transfers often missed the target. The problem is more acute in emerging economies as the shares of taxes and social spending in GDP are lower in these countries than in advanced economies. OECD (2011) observes that emerging economies are also much less efficient in correcting the market distribution of income, as they rely much more on consumption taxes than on personal income taxes. Gupta (2014) also concludes that emerging economies, in particular the Latin American ones, are much less efficient in reducing market inequality via taxes and social spending. Byanyima (2019) observes that in Brazil, the tax rate on the most deficient $10 \%$ is higher than that of the top $10 \%$. Lawson \& Martin (2018) accordingly concludes that economic inequality in a country depends more on the political will of its government than its total stock of wealth.

Dwelling on the political economy angle of rising of inequality Atkinson (2015) argues that the rich can influence government policy in order to protect their wealth. When governments prioritise low inflation over low unemployment or low taxes over investment in health 
infrastructure and education, they are responding to the preferences of the rich. Wealthy citizens not only cast their vote but also influence elections through other means like donations. In this sense, excessive wealth inequality can undermine democracy (Basu, 2017).

Rampant rent-seeking has been cited as another contributing factor to inequality. An individual who invests in something that will not improve the productivity of the economy but only raises his own income from some special undue favour, is a rent seeker (Tullock, 1980). Rent-seeking can include corruption, license capturing, piracy, lobbying the government for undue favour. Thus rent-seeking is like trying to get a larger slice of the cake, without expanding the size of the cake. It is a zero-sum game where the rent seeker's gain is somebody else's loss. In this context, some authors seek to distinguish between 'good inequality' and 'bad inequality' (Rodrik, 2014). Inequality arising from rent-seeking is labelled as bad as it does create new wealth for society. The idea of good inequality, on the other hand, is based on the conventional equity efficiency trade-off. The proponents of good inequality believe that firms and individuals need the prospect or incentive of moving up by taking up productive investments which while securing higher income for the investors also make available higher volume goods and services for the use of the society at large.

Given that some inequality is inevitable in modern-day society, many scholars have now turned their attention to decomposing total inequality into 'fair inequality' and 'unfair inequality' (Checchi et al., 2010; Hussey \& Jetter, 2017). An individual's well-being is expected to be determined partly by his/her choice and partly by circumstances beyond the individual's control. Roemer (1998) labels factors over which individuals have control as "effort", and factors for which individuals cannot be held responsible as "circumstances" Unfair inequality is understood as that part of inequality which is attributable to circumstantial factors such as race, caste, gender a. over which the individual has no control (Brunori, 2016). On the other hand, inequality arising from individuals moving ahead up the ladder by sheer "effort" is considered fair. The ethical principle underlying the distinction between fair and unfair inequality is that any inequality due to circumstances beyond individual control being unfair should be eliminated. Atkinson (2015), however, argues that once intergenerational considerations are brought in, branding inequality arising from inequality of opportunities as unfair and the rest of the inequality as fair may not make much sense. He writes:

Inequality of outcome among today's generation is the source of the unfair advantage received by the next generation. If we are concerned about equality of opportunity tomorrow, we need to be concerned about inequality of outcome today" (Atkinson, 2015, p. 11).

\section{Why Inequality Cannot be Left Unattended}

The post-globalisation period of growing income inequality also saw a large number of people coming out of absolute poverty, especially in developing countries including India (Bhagwati and Panagariya 2014). This has induced some economists to hold the view that there is no need to get worked up about growing inequality so long as the standard of living of those at the bottom stratum of the income distribution keeps improving (Dabla-Norris et al, 2015). However, works reviewed below tend to suggest that growing inequality can be ignored in the long run only at the risk of our own peril.

Both Marx and Keynes hinted at the risk's inequality pose to growth when uneven capital accumulation and saving reduce consumption and demand. More equal economies have been found to have longer spells of growth than those characterised by strong inequality (Berg and Ostry, 2011; Ostry et al., 2014). Easterly (2007) finds empirical evidence from historical data that high structural inequality is a significant barrier to the prosperity as well as good quality institutions and schooling. Khoo and Dennis (1999) find from a cross-country study of the period 1960 and 1985 that income inequality has a negative effect on economic growth. High inequality threatens long-term growth, as there 
is too little investment in human capital. Inequality also tends to reduce social mobility (Gupta, 2014) and can threaten social and political stability and security, thus requiring more public and private spending on crime control and prevention. Such expenditures crowd-out other more productive and growthenhancing spending. Perotti (1996) advances a further reason why income inequality will be harmful to growth. He points out that an unequal distribution of income will lead to pressure for redistribution of income through distortionary taxes and government spending, which can jeopardise growth.

Examining historical evidence, Scheidel (2017) concludes that major consequences of inequalities are wars, revolutions, state failures and pandemics. Wilkinson and Pickett (2009) also find that high levels of inequality results in malfunctioning society, which adversely affects the mental health of the society members, increases violence, crime and suicide rates and educational failure resulting in low social mobility. As Roser (2019, p. 6) put it:

The inequality that we see in the world today is the consequence of unequal progress. Our generation has the opportunity - and responsibility I believe - to allow every part of the world to develop and transform into a place where health, access to education, and prosperity is a reality (Roser, 2019, p.6).

\section{Conclusion}

Given that growing inequality can be a threat in itself for social and economic stability, in the long run, policy attentions are required to address it. The traditional approach of taxes and transfers should undoubtedly be a component of the policy package. Nevertheless, this conventional approach has its own limitation in several forms. If taxes are too high, the incentive for investments may be adversely affected which in turn can reduce the rate of growth which can make the task of reducing inequality more difficult. Moreover, many newly emerging and developing countries may not be capable of effectively targeting the transfers, resulting in leakages and rent-seeking giving a fillip to so- called bad inequalities. Use of ICT for better information flow, enabling more effective identification of beneficiaries and more efficient delivery of transfers can, of course, cut down such misallocations and leakages.

Given that inequality in many societies has assumed unprecedented magnitude, unconventional and radical forms of transfers are being advocated. The idea of Universal Basic Income has been on the discourse. As for gathering resources for carrying out such transfers, Stiglitz and Piketty's calls for higher wealth and inheritance taxes are now finding greater acceptance among economists and policymakers.

\section{References}

Alesina, A., \& Rodrik, D. (1994). Distributive Politics and Economic Growth. Quarterly Journal of Economics, 109 (2), 465-490. DOI:10.2307/2118470.

Acemoglu, D., \& Robinson, J. A. (2002). The political economy of the Kuznets curve. Review of development economics, 6 (2), 183-203. DOI:10.1111/1467-9361.00149.

Atkinson, B.A. (2015). Inequality: What Can Be Done? London: Harvard University Press.

Basu, K. (2017, April 18). Why reducing inequality could be a matter of survival? World Economic Forum. Retrieved on July 25, 2019, from,

https://weforum.org/agenda/2017/04/whyreducing-inequality-could-be-a-matter-ofsurvival/.

Berg, A. G., \& Ostry, J. D. (2011). Inequality and Unsustainable Growth: Two Sides of the Same Coin? Staff Discussion Note 11/08. International Monetary Fund, Washington D C Retrieved on June 16, 2019, from, https://www.imf.org/external/pubs/ft/sdn/201 1/sdn1108.pdf.

Bhagwati, J. \& Panagariya A. (2014). Why Growth Matters, USA: A Council of Foreign Relation Books, Public Affairs: New York.

Bishop, J.A., Formby, J. P., \& Paul D. T. (1992). Explaining Interstate Variation in Income 
Inequality. The Review of Economics and Statistics, 74 (3), 553-557.

Bourguignon, F. (2015). The Globalization of Inequality, USA: Princeton University Press, Princeton and Oxford.

Brunori, P. (2016). How to measure inequality of opportunity: a hands-on guide. LCC Working Paper No: 2016-04. Institute for Social Science Research, University of Queensland.

Byanyima, W. (2019, January, 21). The shocking truth about inequality today. World Economic Forum. Retrieved on July 15, 2019, from, https://weforum.org/agenda/2019/01/theshocking-truth-about-inequality-today/.

Checchi, D., Peragine, V., \& Serlenga, L. (2010). Fair and unfair income inequalities in Europe. ECINEQ working paper 174, Society for the Study of Economic Inequality.

Corlett, A. (2016). Examining an elephant: globalization and the lower middle class of the rich world. Resolution Foundation Report, London. Retrieved on July 25, 2019, from, https://www.resolutionfoundation.org/app/upl oads/2016/09/Examining-an-elephant.pdf.

Dabla-Norris, Kochnar, E.K., Suphaphiphat, N., Ricka, F., and Tsounta, E. (2015). Causes and consequences of income inequality: A Global Perspective. IMF Staff Discussion Note SDN/15/15. Retrieved on January 11, 2020, from, https://www.imf.org/external/pubs/ft/sdn/201 5/sdn1513.pdf.

Deaton, A. (2013). The Great Escape: Health, Wealth, and the Origins of Inequality. Princeton University Press, Princeton and Oxford.

Easterly, W. (2007). Inequality does cause underdevelopment: Insights from a new Instrument. Journal of Development Economics, 84(2), 755-776. DOI:

10.1016/j.jdeveco.2006.11.002.

Gupta, S. (2014). Fiscal Policy and Income Inequality. IMF Policy Paper, International Monetary Fund, Washington, D.C. Retrieved on January 11, 2018, from, https://www.imf.org/external/np/pp/eng/2014 /012314.pdf.
Hussey, A., \& Jetter, M. (2017). Long Term Trends in Fair and Unfair Inequality in the United States. Applied Economics, 49(12), 11471163. DOI: $10.1080 / 00036846.2016 .1213362$.

Jacobs, D. (2000). Low inequality with low redistribution? An analysis of income distribution in Japan, South Korea and Taiwan compared to Britain. CASE papers case 33, Centre for Analysis of Social Exclusion, London School of Economics, Houghton Street, London.

Kaldor, N. (1955). Alternative Theories of Distribution. The Review of Economic Studies, 23(2), 83-100. Retrieved on January 18, 2018, from, www.jstor.org/stable/2296292.

Khoo, L., \& Dennis, B. (1999). Income Inequality, Fertility Choice, and Economic Growth: Theory and Evidence. Papers 687, Harvard-Institute for International Development, Cambridge, MA.

Kurian N.J. (2000). Widening Regional Inequalities in India: Some Indicators. Economic and Political Weekly, 35(7), 538-550.

Kuznets, S. (1955). Economic Growth and Income Inequality. The American Economic Review, 45(1), 1-28. Retrieved on May 11, 2017, from, www.jstor.org/stable/1811581.

Kuznets, S. (1963). Quantitative Aspects of the Economic Growth of Nations: VIII, Distribution of Income by Size, Economic Development and Cultural Change, 11(2), 1-80.

Lakner, C., \& Milanovic, B. (2016). Global Income Distribution: From the fall of the Berlin Wall to the Great Recession. The World Bank Economic Review, 30(2), 203-232.

Milanovic, B. (2018, December 10). The Inequality Paradox: Rising Inequalities Nationally, Diminishing Inequality Worldwide. Pro-Market [Blog post]. Retrieved on March 20, 2019, from, https://promarket.org/theinequality-paradox-rising-inequalitiesnationally-diminishing-inequality-worldwide/

Organization for Economic Co-operation and Development (OECD) (2011). Divided We Stand: Why Inequality Keeps Rising. OECD Publishing. DOI: 10.1787/9789264119536-en. 
Okun, A. M. (2015). Equality and Efficiency: The Big Trade off, Brookings Institution Press, Washington, D.C.

Ostry, J. D., Berg, A., \& Tsangarides, C.G. (2014). Redistribution, Inequality and Growth. IMF Staff Discussion Note 14/02, International Monetary Fund, Washington, D.C. Retrieved on September 28, 2017, from, http://www.imf.org/external/pubs/ft/sdn/2014 /sdn1402.pdf.

Lawson, M. \& Martin, M. (2018). The Commitment to Reducing Inequality Index 2018: A global ranking of governments based on what they are doing to tackle the gap between rich and poor, Oxfam, October, 2018, Development-Finance International. DOI: 10.21201/2018.3415

Perotti, R. (1996). Growth, Income Distribution, and Democracy: What the Data Say. Journal of Economic Growth, 1(2), 149-187. Retrieved on March 26, 2017, from, www.jstor.org/stable/40215914.

Persson, T., \& Tabellini, G. (1994). Is Inequality Harmful for Growth? The American Economic Review, 84(3), 600-621. Retrieved on December 25, 2017, from, www.jstor.org/stable/2118070.

Piketty, T. (2014). Capital in the Twenty-First Century. Translated by Arthur Goldhammer. Cambridge, Mass.: Belknap Le capital au XXIe siècle. Paris: Edition du Seuil, Havard University Press.

Piketty, T. (2015). The Economics of Inequality. The Belknap Press of Harvard University Press, Cambridge, Massachusetts and London.

Rao V. V. B. (1999). East Asian Economies:

Trends in Poverty and Income Inequality. Economic and Political Weekly, 34(18), 1029-1039. Retrieved on November 18, 2017, from, www.jstor.org/stable/4407905.

Rodrik D. (2014, December 11). Good and Bad Inequality. Project Syndicate, Retrieved on July 25, 2019, from, https://www.projectsyndicate.org/commentary/equality-economicgrowth-tradeoff-by-dani-rodrik-201412 ?barrier=accesspaylog.
Roemer, J. (1998). Equality of Opportunity. Harvard University Press, Cambridge, MA, USA.

Roser, M. (2019, August 28). Global Inequality of Opportunity, Our World in Data. Retrieved on September 25, 2019, from, https://ourworldindata.org/global-inequalityof-opportunity.

Roy, R.P., \& Roy, S.N. (2018). Structural change, Trade and Inequality Cross Country Evidence. In S. Paul (Ed.), Kuznets beyond Kuznets: Structural Transformation and Income Inequality in the Era of Globalization in Asia (pp. 93-131). Asian Development Bank Institute, Tokyo, Japan.

Sarkar, S., \& Mehta, B. (2010). Income Inequality in India: Pre- and Post-Reform Periods. Economic and Political Weekly, 45(37), 45-55. Retrieved on June 28, 2018, from, www.jstor.org/stable/25742070.

Scheidel, W. (2017). The Great Leveler: Violence and the History of Inequality from the Stone Age to the Twenty-First Century. Princeton University Press, Princeton and Oxford.

Stiglitz, J. (2012). The Price of Inequality. New York: Norton.

Stiglitz, J. (2013, October 13). Inequality is a Choice. New York Times, Retrieved on January 22, 2018, from, https://opinionator.blogs.nytimes.com/2013/1 0/13/inequality-is-a-choice/.

The Economist. (2016). Global inequality: Shooting an elephant, Charting globalization's discontents., Print Version, September 17.

Todaro, M. and Smith (2013). Economic development and Growth (Tenth Edition): Pearson publication, New Delhi, India.

Tullock, G. (1980). Rent seeking as a negative sum game. In J. M. Buchanana, R.D. Tollison \& G. Tullock, (Ed.), Toward a Theory of the Rentseeking Society (pp 16-38). Texas A \& M University Press.

Vanham, P. (2018, September 18). The story of Vietnam's economic miracle. World Economic Forum. Retrieved on February 12, 2019, from, https://www.weforum.org/agenda/2018/09/ho w-vietnam-became-an-economic-miracle/. 
Wilkinson, R. \& Pickett, K. (2009). The Spirit Level: Why greater equality makes societies stronger? Bloomsbury Press, New York, London, Penguin.

Wolff, E. N. (2009). Poverty and income distribution. Blackwell Publication.
Yan, N. (2016, October 2). Automated Inequality. Harvard Political Review. Retrieved on July 22, 2018 from,

https://harvardpolitics.com/world/automation/ 